\title{
Abnormal Spindles in Second Meiosis in Canola (Brassica napus and Brassica campestris)
}

\author{
Alice Maria de Souza ${ }^{1}$, Maria Suely Pagliarini ${ }^{1 *}$ and Ivo Marcos Carraro $^{2}$ \\ ${ }^{I}$ Department of Cell Biology and Genetics, State University of Maringá, 87020-900 Maringá-PR, Brazil; ${ }^{2}$ Central \\ Agricultural Cooperative for Technological and Economic Development Ltd., 85806-970 Cascavel-PR, Brazil
}

\begin{abstract}
Studies were carried out on the occurrence of abnormal spindles in the second meiotic division in some canola cultivars recently introduced in Brazil. Fusion of spindles was observed in metaphase II rejoining the two sets of chromosomes segregated in anaphase I and also sequential and tripolar spindles were discovered rejoining two sets of chromatids segregated in anaphase II. The frequency of cells with abnormal spindles ranged from 3.18 to $8.10 \%$. The results suggested that this abnormality was caused by environmental stress that affected the plants during the blooming period.
\end{abstract}

Key words: Canola, Brasssica napus, Brassica campestris, Abnormal spindles, Unreduced gametes

\section{INTRODUCTION}

For several decades, rapeseed had been used for animal feeds in the South of Brazil, but due to its toxicity, it was replaced by other forage plants. However, with the development of cultivars with low erucic acid and glucosinolate content, this cultivar now called canola, regained popularity in the 1980s. Since the number of local cultivars was low, new cultivars were brought from Canada, Sweden, Argentina, and Germany for breeding purposes. The introduction of varieties originating from cold climates into a hot region stimuled various studies on the meiotic behavior of the plants and to correlate it with productivity, since canola is used nowadays mainly for the manufacture of edible oil. During meiotic analysis of eleven canola cultivars, belonging to the species Brassica napus $(2 \mathrm{n}=38)$ and B. campestris $(2 n=20)$, chromosome stickiness (Souza \& Pagliarini, 1996) and cytomixis (Souza \& Pagliarini, 1997) among other abnormalities (Souza et al., 1997) was detected. The present paper describes the occurrence of abnormal spindles and unreduced gamete formation in some cultivars.

\section{MATERIAL AND METHODS}

The investigated materials belonged to the canola germplasm collection of the Central Agricultural Cooperative for Technological and Economic Development Ltd. (COODETEC), located in Cascavel (Paraná State). Eleven recently introduced canola cultivars were assessed for meiotic behavior, among them four belonged to Brassica campestris var. oleifera (SV 03774, SV 03775, SW 03301 and Parkland) and seven to Brassica napus var. oleifera (CTC 4, Iciola 41, Alto, PFB2, B1606, Hyola 401 and Tobin). The cultivars Parkland, Tobin, B 1606 and Hyola 401 originate from Canada; PFB 2 from Germany; SV 03774, SV 03775 and SW 03301 from Sweden; Iciola 41 and Alto from Argentina, while cultivar CTC 4 being grown in the State of Rio Grande do Sul, results from mass selections carried out on the German cultivar Erglu, introduced in the country by the Regional Wheat Cooperative Ltd. (COTRIJUI-RS) in the 1970s.

A total of ten plants per cultivar were analyzed and more than 300 cells per plant were investigated for meiotic behavior. Flower buds were fixed in Carnoy ( 1 part acetic acid: 3 parts

\footnotetext{
* Author for correspondence
} 
alcohol) for 24 hours, transferred to $70 \%$ alcohol and stored under refrigeration. Microsporocytes were prepared by the squash technique and stained with $1 \%$ propionic carmine.

\section{RESULTS AND DISCUSSION}

Among the eleven analyzed cultivars, four belonging to $B$. campestris and five to $B$. napus exhibited abnormal spindles during the second meiotic division of the pollen mother cells. The percentage of cells with this abnormality ranged from 3.18 in SV 3775 to 8.10 in the Iciola 41 cultivar (Table 1). Canola as a dicotyledonous species presented simultaneous cytokinesis, so that both sets of chromosomes in the secondary microsporocytes shared the cytoplasm of the same cell. Different types of abnormal spindles were observed. In Figure 1A, a microsporocyte of $B$. campestris shows fusion of spindles in metaphase II and rejoining of chromosomes segregated in the first division. Figure 1B shows the same phenomenon in B. napus. Sequential bipolar (Figure 1C) and tripolar spindles (Figure 1D), instead of parallel ones, were observed in B. napus. In the cases A and B, two unreduced gametes would be formed, and in $\mathrm{C}$ and $\mathrm{D}$, two gametes would be reduced and one would be unreduced.

The spindle apparatus is normally bipolar and acts as a single unit, playing a crucial role in the alignment of metaphase chromosomes and their poleward movement during anaphase (Nirmala \& Rao, 1996). Distortion in meiotic spindles can be responsible for unreduced gamete formation. Aberrant spindles during the second division causing rejoining of the first division products have been widely reported in potatoes. Three types of aberrant spindles have been found in this species: (i) second division spindles lying next to each other (Mok \& Peloquin, 1975); (ii) tripolar spindles (Veilleux et al., 1982); (iii) fusion of the second division spindles to form a large one (Ramanna, 1979). The latter two types were found in the Brassica cultivars analyzed here. Unreduced gamete formation due to disorientation of spindles at metaphase II has been reported in Medicago (Vorsa \& Bingham, 1979), as well as fusion of adjacent nuclei in Lolium perenne (Chen et al., 1997) and tripolar spindles in Ochna ( Pagliarini et al., 1992) and Centella asiatica (Consolaro et al., 1996).

The formation of $2 \mathrm{n}$ gametes has been investigated both for studies of evolution (Harlan \& De Wet, 1975) and for breeding programs (Veilleux, 1985). Most species with a polyploid series have relied upon $2 \mathrm{n}$ gametes for the evolution of cultivated forms through sexual polypoidization (Harlan \& De Wet, 1975). Breeders of many vegetatively propagated crops have been taking advantage of the occurrence of $2 n$ gametes from wild diploid species for their cultivated polyploid crops through ploidy manipulation (Peloquin \& Ortiz, 1992). Unilateral or bilateral polyploidization through the action of $2 \mathrm{n}$ gametes has been used for genetic improvement in many crops (see Ortiz, 1997). Although $2 \mathrm{n}$ gametes could be formed through several mechanisms, the result always has been unreduced gametes formed by first division restitution (FDR) or by second division restitution (SDR). Polyploids resulting from FDR and SDR were different in genetic composition and breeding value. According to Mendiburu \& Peloquin (1977), unreduced gametes formed by FDR theoretically transmited a large portion (approximately 80\%) of parental heterozygosity to polyploid offspring, whereas the SDR transmited approximately $40 \%$. In B.napus and B. campestris, the microspores originated by total fusion of spindles, like in Figures $1 \mathrm{~A}-\mathrm{B}$, were genetically equivalent to FDR because the chromosomes segregated in anaphase I were rejoined, and the second division would be equational (identical to a mitosis). Both unreduced gametes were identical, and the favorable allelic combinations would be preserved. The single unreduced gamete originated by the aberrant spindle orientation, like in Figures 1C-D, is genetically identical to SDR because the $2 n$ nucleus is a restitutional nucleus organized after segregation of homologous chromosomes in anaphase I. To obtain success in crossing with another parental tetraploid in potatoes, Quinn et al. (1974) stated that the donor must produce at least $5 \%$ of unreduced gametes. The observed frequency of cells with abnormal spindles $(3.18-8.10)$ in $B$. napus and $B$. campestris has been closely similar to the frequency ranges reported for other genera. The frequency of $2 \mathrm{n}$ pollen in Actinidia, for example, ranged from 0.7 to 10.3 (Yan et al., 1997) and was lower in Avena vaviloviana, reaching $1.0 \%$ (Katsiotis \& Forsberg, 1995). 
Table 1. Frequency of cells with abnormal spindles in the second division of microsporogenesis in B.napus and B. campestris.

\begin{tabular}{cccc}
\hline Species & Cultivar & No. of analyzed cells & $\begin{array}{c}\text { \% of cells with aberrant } \\
\text { spindles }\end{array}$ \\
\hline B. campestris & SV 3774 & 3926 & 5.45 \\
& SV 3775 & 4435 & 3.18 \\
& SW 03301 & 3945 & 3.63 \\
& Parkland & 3842 & 6.10 \\
B.napus & & 3705 & \\
& Alto & 3953 & 4.64 \\
& Iciola & 3446 & 4.10 \\
& Tobin & 4939 & 4.45 \\
& CTC 4 & 4195 & 5.32 \\
\hline
\end{tabular}

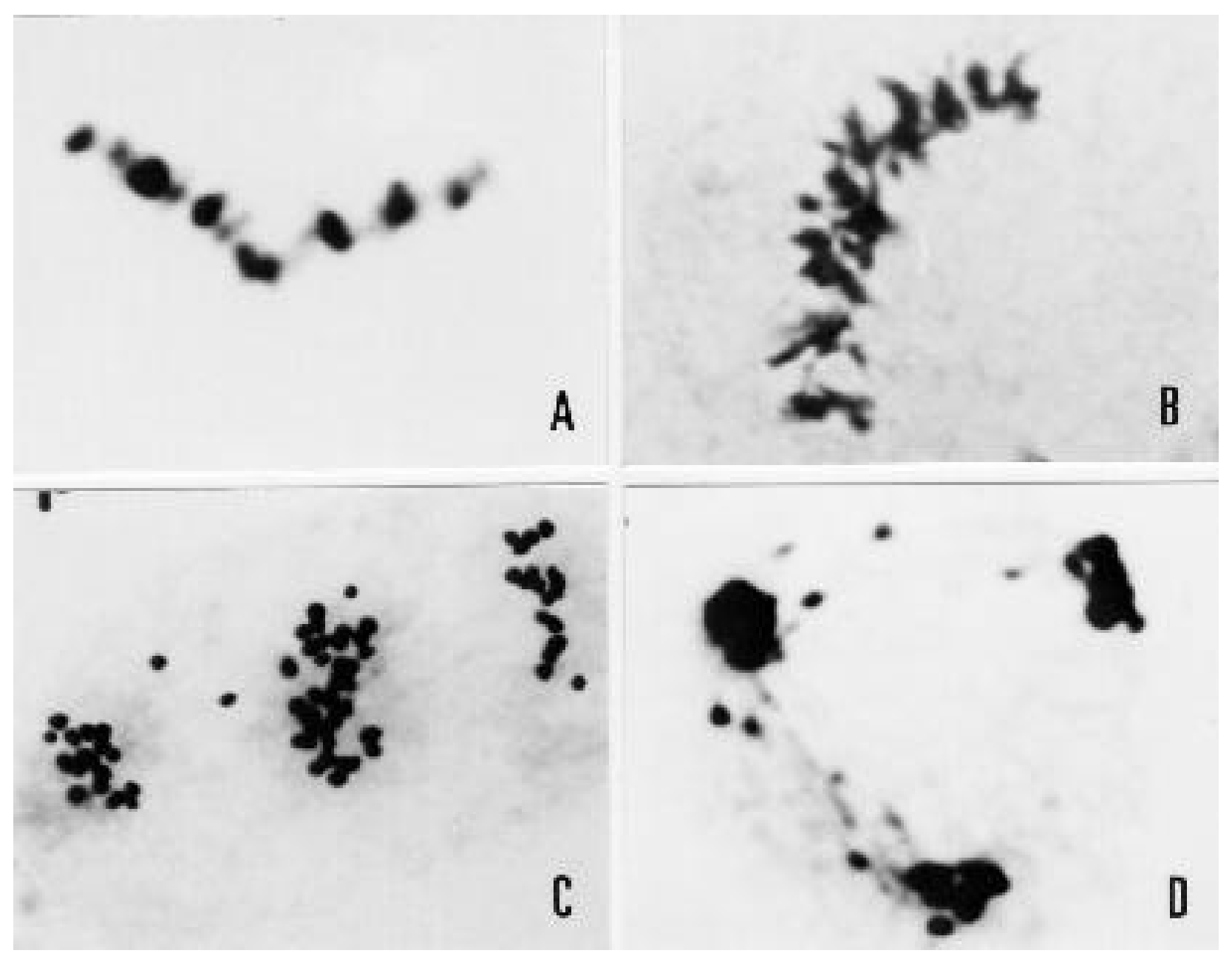

Fig. 1. Some aspects of aberrant spindles in B. napus and B. campestris. A) A microsporocyte of B. campestris in metaphase II showing fusion of spindles and rejoining of chromosomes. B) The same phenomenon in B. napus. C) Anaphase II showing a sequential bipolar spindle in B.napus rejoining two set of chromatids. D) Telophase II showing tripolar spindles in $B$. napus originating a restitutional nucleus. 
Although the production of $2 \mathrm{n}$ gametes is under genetic control (Sala et al., 1989, Katsiotis \& Forsberg, 1995; Calderini \& Mariani, 1997) it can also be affected by environmental conditions. Stein (1970) listed several species in which the frequency of $2 n$ gametes varied with the cultivation conditions. In some clones of Solanum temperature levels showed influence on the formation of unreduced pollen (Veilleux \& Lauer, 1981; Mchale, 1983), whereas in alfalfa the frequency of $2 \mathrm{n}$ megaspores was three times higher in the field than in a growth chamber (Barcaccia et al., 1997). According to Veilleux et al. (1982), it was not possible to identify the environmental components that affected the frequency of unreduced gametes because there was a great genotype $x$ environment interaction. The eleven analyzed cultivars were derived from countries of cold climates and introduced into a hot region. During the blooming period the cultivars were affected by high temperature and water deficiency which greatly affected their development. Since abnormal spindles were never described in plants cultivated under ideal conditions for the crop, our results suggested that occurrence of the abnormality might be caused by the environmental stress to which the plants were submitted.

Over the last few years, many authors have described $2 \mathrm{n}$ gamete formation, but most of them have evaluated only the pollen size and the mechanisms of origin remained unknown. The present paper elucidates this mechanism in canola. Unreduced gametes in B.napus and $B$. campestris could be useful in breeding programs.

\section{RESUMO}

O presente estudo descreve a ocorrência de fusos anormais na segunda divisão meiótica em algumas cultivares da canola recentemente introduzidas no Brasil. Fusão de fusos foi observada em metáfase II reunindo os dois conjuntos cromossômicos segregados na anáfase
I; fusos sequenciais e tripolares reunindo cromátides segregadas na anáfase II também foram observados. A frequência de células com fusos anormais variou de 3,18 a $8,10 \%$ entre as variedades. Os resultados sugerem que estas anormalidades foram causadas por condições climáticas adversas que afetaram as plantas no período de florescimento. As implicações genéticas destas anormalidades são descritas.

\section{REFERENCES}

Barcaccia, G.; Tavoletti, S.; Falcinelli, M. \& Veronesi, F. (1997), Environmental influences on the frequency and viability of meiotic and apomeiotic cells of a diploid mutant of alfalfa. Crop Sci., 37, 70-76.

Calderini, O. \& Mariani, A. (1997), Increasing $2 \mathrm{n}$ gamete production in diploid alfalfa by cycles of phenotypic recurrent selection. Euphytica, 93, 113-118.

Chen, C.; Sleper, D.A.; Chao, S.; Johal, G.S. \& West, C.P. (1997), RFLP detection of $2 n$ pollen formation by first and second division restitution in perennial ryegrass. Crop Sci., 37, 76-80.

Consolaro, M.E.L.; Pagliarini, M.S. \& Chaves, L.J. (1996), Meiotic behavior, pollen fertility and seed production in Brazilian populations of Centella asiatica (L.) Urban (Umbelliferae). Cytologia, 61, 375-381.

Harlan, J.R. \& De Wet, J.M.J. (1975), On Ö Winge and a prayer: The origins of polyploids. Bot. Rev., 41, 361-390.

Katsiotis, A., \& Forsberg, R.A. (1995), Discovery of $2 \mathrm{n}$ gametes in tetraploid oat Avena vaviloviana. Euphytica, 81, 1-6.

Mchale, N.A. (1983), Environmental induction of high frequency $2 \mathrm{n}$ pollen formation in diploid Solanum. Can. J. Genet. Cytol., 25, 609-615.

Mendiburu, A.O. \& Peloquin, S.J. (1977), The significance of $2 \mathrm{n}$ gametes in potato breeding. Theor. Appl. Genet., 49, 53-61.

Mok, D.W.; Peloquin, S.J. (1975), Three mechanism of $2 \mathrm{n}$ pollen formation in diploid potatoes. Can. J. Genet. Cytol., 17, 217-225. 
Nirmala, A. \& Rao, P.N. (1996), Genesis of chromosome numerical mosaicism in higher plants. The Nucleus, 39, 151-175.

Ortiz, R. (1997), Occurrence and inheritance of 2n pollen in Musa. Ann. Bot, 79, 449-453.

Pagliarini, M.S.; Martinez, M. \& Silva, I. (1992), Some observations on the cytology in Ochna sp (Ochnaceae). Cytologia, 57, 237-400.

Peloquin, S.J. \& Ortiz, R. (1992), Techniques for introgressing unadapted germoplasm to breeding populations. In: H. T. Stalker, and J. P. Murphy (eds.), Plant Breeding in the 1990s, 485-507, CAB International, UK.

Quinn, A.A.; Mok, D.W.S. \& Peloquin, S.J. (1974), Distribution and significance of diplandroids among the diploid Solanum. Amer. Pot. J., 28, 537-561.

Ramanna, M.S. (1979), A re-examination of the mechanisms of $2 \mathrm{n}$ gamete formation in potato and its implications for breeding. Euphytica, 28, 537-561.

Sala, C.A.; Camadro, E.L.; Salaberry, M.T. \& Mendiburu, A.O. (1989), Cytological mechanism of $2 \mathrm{n}$ pollen formation and unilateral sexual polyploidization in Lolium. Euphytica, 43, 1-6.

Souza, A.M. \& Pagliarini, M.S. (1966), Spontaneous chromosome stickiness in canola. The Nucleus, 39, 85-89.

Souza, A.M. \& Pagliarini, M.S. (1997), Cytomixis in Brassica napus var. oleifera and Brassica campestris var. oleifera (Brassicaceae). Cytologia, 62, 25-29.

Souza, A.M.; Pagliarini, M.S.; Brandão-Filho, J.U.T.; Carraro, I.M. \& Balbino,.L.C. (1997), Evaluation of meiotic behavior in canola
(Brassica napus var. oleifera and Brassica campestris var. oleifera) cultivars recently introduced in Brazil. The Nucleus,.40, 95-100.

Stein, M. (1970), Polyploidie und Umwelt. Tagungsberichte Deustchen Akad. Wiss., 101, 51-68.

Veilleux, R.E. (1985), Diploid and polyploid gametes in crop plants: Mechanisms of formation and utilization in plant breeding. In: J. Janick (ed.), Plant Breed, 253-288, Avi Publish CO., Wesport.

Veilleux, R. E.; Mchale, N.A. \& Lauer, F.I. (1982), 2n gametes in diploid Solanum: Frequency and types of spindle abnormalities. Can. J. Genet. Cytol., 24, 301-314.

Veilleux, R.E. \& Lauer, F.I. (1981), Variation for $2 \mathrm{n}$ pollen production in clones of Solanum phureja Juz. and Buk. Theor. Appl. Genet. , 59, 95-100.

Vorsa, N. \& Bingham, E.T. (1979), Cytology of $2 \mathrm{n}$ pollen formation in diploid alfalfa, Medicago sativa. Can. J. Genet. Cytol., 21, 525-530.

Yan, G.; Fergunson, A.R.; Mcneilage, M.A. \& Murray, B.G. (1997), Numerically unreduced (2n) gametes and sexual polyploidization in Actinidia. Euphytica, 96, 267-272.

Received: June 06, 1998; Revised: June 30, 1998; Accepted: November 04, 1998. 